\title{
Changes in soft tissue profile during the treatment of Class III malocclusion treated with Class III activator
}

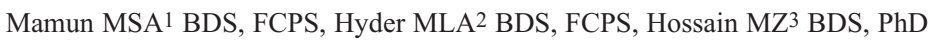

ABSTRACT

Objective: This longitudinal retrospective cephalometric study was undertaken in an attempt to evaluate the effect of Class III activator on the soft tissue structures in subjects with skeletal Class III.

Methods: The material consisted of cephalometric films of 26 Class III patients (13females and 13 males, with a mean age of $13.58 \pm 4.38$ years). Each treated patient was matched before treatment with Class III subject for sex and age. Differences at $\mathrm{T} 1$ and $\mathrm{T} 2$ were examined using paired t-test.

Results: After treatment the patients' soft tissue profile improved significantly compare with before treatment.

Conclusion: Soft tissue changes were found in patients treated by Class III activator in skeletal Class III patients.

Clinical relevance: Class III activator may be an efficient method to improving soft tissue facial profile in Skeletal Class III malocclusion.

Keywords: Skeletal Class III, Class III Activator, Soft tissue profile (Bangladesh Journal of Orthodontics and Dento Facial Orthopedics, Vol. 2, No. 2, April 2012, p 24-29).

\section{INTRODUCTION}

The final goal of any orthodontic treatment should be not only to obtain good function but also to improve facial attractiveness. The main focus of concern for the Class III patient, presenting a concave facial profile, a retrusive nasomaxillary area, and a protrusive lower face and lip, may be the profile rather than the occlusion. However, achieving a harmonious soft tissue profile is sometimes difficult because a Class III malocclusion is one of the most challenging problems confronting the orthodontist. ${ }^{1}$

Class III malocclusion is a condition in which the lower molars are positioned mesial to the upper molars; lower front teeth are more prominent than the upper front teeth. The clinical presentation of Class III malocclusion has a large spectrum ranging from edge to edge bite to reverses overjet with extreme variation of underlying skeletal jaw bones, usually concave profile. Individual with Class III malocclusion may have a combination of skeletal and dentoalveolar component deformities. ${ }^{2}$ The components of Class III malocclusion can be grouped into following categories: ${ }^{3}$

\section{Dentoalvelar class III}

2. Functional class III ( pseudo Class III)

3. Class III malocclusion with retruded maxilla

4. Class III malocclusion with mandibular prognathism

5. Class III malocclusion with combination of retruded maxilla and mandibular prognathism

6. Combination of above with varying degree of severity.

Early treatment is commonly indicated for Class III individuals because if left untreated they will ultimately comprise a substantial percentage of patients seeking orthognathic surgery as adults. Therapeutic regimes designed to influence the facial morphology during the growth period include functional approaches, $4-7$ chincup therapy, ${ }^{8-12}$ extraoral traction to the mandibular dentition, ${ }^{13-15}$ reverse headgears, or facemasks. ${ }^{16-18}$

Activator is a loose fitting removable appliance which redirects the pressures of the facial and masticatory muscle on the tooth and supporting structures to produce improvements in the tooth arrangements and occlusal relations.

Figure: 1 Class III activator used in this study
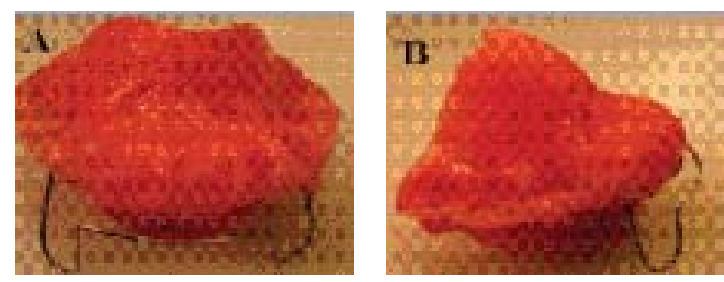

Class III activator Frontal view (A) and Lateral view (B).

Activator is used to correct mainly jaw relation or adjunct treatment with fixed appliance to minimize the treatment time and complication of fixed appliance therapy. Though early orthopaedic correction is a good choice to correct or reduce the 
amount of skeletal \& dental discrepancy 11,19 the Class III activator can be used successfully in aged patients (non-growing individuals) if the functional or manual guided position of mandible is comfortable or tolerable for the patients 20,21

The skeletal and dentoalveolar effects of various orthopedic approaches used in Class III malocclusions have been reported extensively, whereas available literature comparing the soft tissue responses to treatment, $5,14,22-24$ and comparison of effects of different treatment applications is limited.6,15,25 The purpose of this study was to evaluate the treatment effects of Class III Activator therapies on the soft tissue profiles of subjects having Class III skeletal malocclusion and to compare the changes.

\section{MATERIALS AND METHODS}

\section{Source of materials}

Subjects: from the patients referred to the Department of Orthodontics and Dentofacial Orthopedics, Dhaka Dental College and Hospital, Mirpur-14, Dkaha-1206 and Private Orthodontic Clinic ( Ortho Dental Care), Dhanmondi, Dhaka.

Cphalometric Radiographs: as standardized cephalometric radiographs were prerequisites for this study so other organizations such as Prescription point Pvt. Itd, Lab aid Hospital Pvt. Ltd., Popular Diagnostic etc providing cephalometric radiographs.

\section{Selection criteria}

Inclusion criteria:

* Skeletal Class III malocclusion

* Anterior cross bite

* Growing and grown up individuals whose brought backward as willingly or manually

Exclusion criteria:

* Severe crowding

* Class III malocclusion with Anterior open bite

* Whose mandible cannot brought backward as willingly or manually

* Non cooperative patient

Landmarks Used in this Study:

Figure: 2 Landmarks

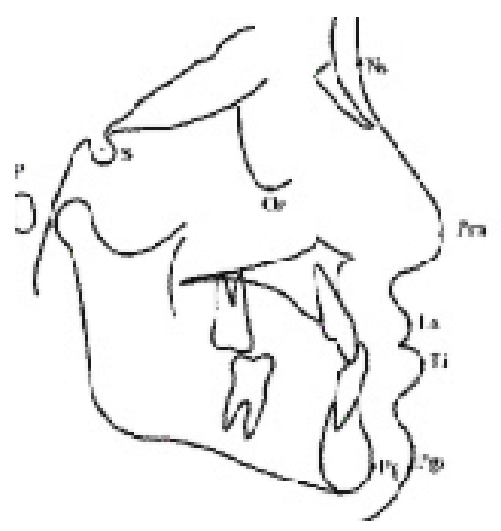

Prn: soft tissue tip of the nose, $\mathrm{Pg}$ Pogonion Pgs: Soft tissue Pogonion, Ls: labiale superior; Li: labiale inferior, Or (Orbitale), $\mathrm{P}$ (Porion), Ns Soft tissue Nasion
Lines and linear and angular measurements used in the study: Figure 3 Lines and linear and angular measurements

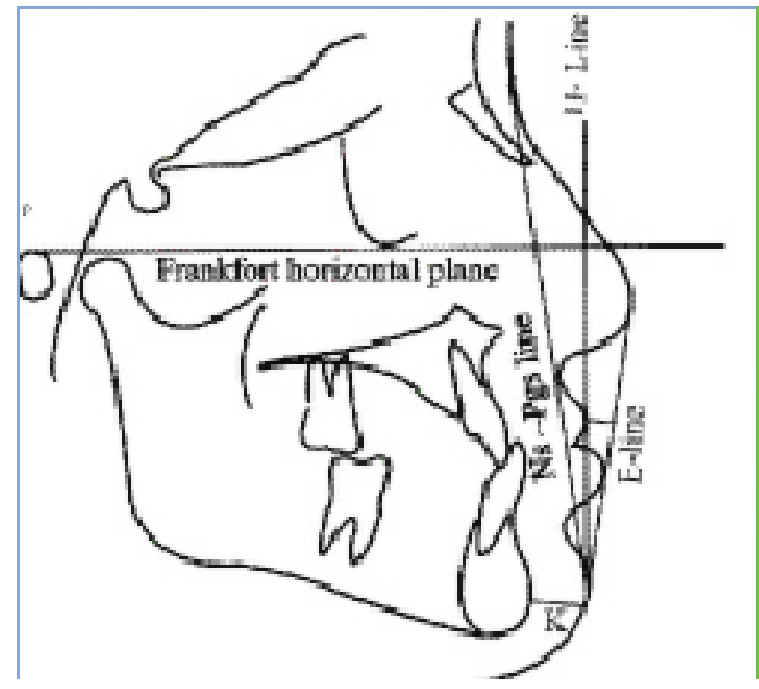

E-line (esthetic line): The aesthetic line (E-line) constructed between Prn (soft tissue tip of the nose and Pgs (soft tissue Pogonion), was used as the soft tissue aesthetic line $\mathrm{H}$ - Line (Harmony line) : tangent to soft tissue Pogonion (Pgs) to upper lip(Ls). Frankfort horizontal plane: horizontal plane passing through porion and orbitale.

A angle (Soft tissue facial angle) : This angle is formed by intersection of soft tissue nasion (Ns)- (Pgs) soft tissue pogonion line and Frankfort Horizontal (FH) Plane, $\mathrm{H}$ angle: Angle between $\mathrm{H}$ line and Ns -Pgs line, Upper lip E-Line: Distance from upper lip (Ls) to Esthetic (E) line (mm), Lower lip E-line: Distance from lower lip (Li) to Esthetic (E) line ( $\mathrm{mm}$ ) K : Soft tissue chin Thickness(mm): Pg (Pogonion) to Pgs (soft tissue Pogonion)

\section{Procedures of Data collection}

For this prospective longitudinal study, 26 patients with Class III malocclusion were selected from the patients referred to the department of Orthodontics and Dentofacial Orthopedics, Dhaka Dental College and Hospital, Mirpur-14, Dkaha-1206 and Private Orthodontic Clinic (Ortho Dental care), Dhanmondi, Dhaka with proper diagnosed by clinical examination, model, photographs, clinical VTO and lateral cephalograms. The subjects were selected conventionally with the fulfillment of selection criteria. The subjects were assigned to treatment with Class III activator. Each subject was asked to wear an Andresen activator for at least 14 hours a day and to keep their lips together to form a lip seal when the appliance being worn. The construction bite for the activator was taken with the incisors in an edge to edge or more backward positioned of the mandible brought as willingly as possible by the patients and separated by $2-3 \mathrm{~mm}$. the mean treatment with activator was 12 months. 
The first radiographs (T1) were taken before appliance delivery, and the second radiographs (T2) were taken after achieving a positive overjet or Class I occlusion (or both) but before secondphase fixed appliance treatment. The lateral cephaloghrams were traced and measured by the same investigator. Soft tissue changes were assessed by three linear and three angular measurements. All procedures such as landmark identification, tracing, and measurement were repeated after a period of 2 weeks by the same author. the linear and angular measurements were made to the nearest $0.5 \mathrm{~mm}$ and 0.5 degree, respectively. The changes during treatment were the cephalometric measurements after activator treatment (T2) minus cephalometric measurements at start of treatment (T1).

To determine the errors associated with the radiographic tracings and the measurements, all radiographs were re-traced and remeasured two weeks after the first procedure. The variables were normally distributed, and there were no significant differences between the first and second set of measurements.

\section{Data analysis}

A paired t-test was applied to determine the changes in cephalometric variables. All statistical analysis will be performed using the standard statistical methods by SPSS software program (SPSS for windows XP, version 17.0)

\section{RESULTS}

Figure-4 Number of the patient

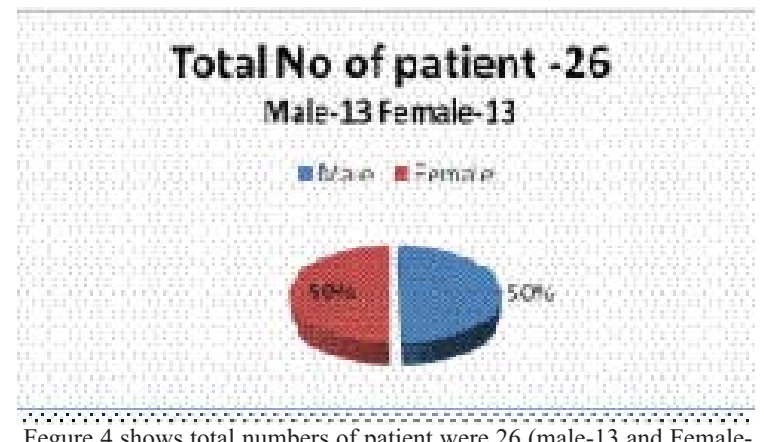

Fegure 4 shows total numbers of patient were 26 (male-13 and Female13)

Figure-5 Age group of the patients

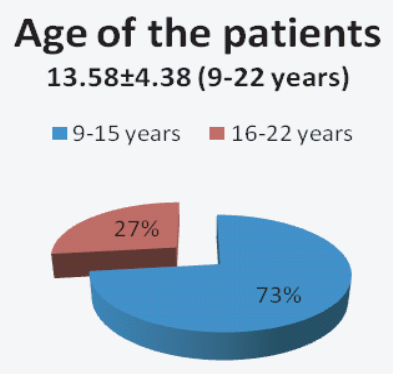

Figure 5 shows the mean age was $13.58 \pm 4.38$ (9-22 years), 9-15 years age group $73 \%$ and $16-22$ years age group $27 \%$.

Table 1 Soft Tissue changes after treatment with Class III activator

\begin{tabular}{|c|c|c|c|c|c|c|}
\hline & Variables & $\begin{array}{l}\text { Before } \\
\text { Treatment } \\
\text { Mean } \pm \text { SD }\end{array}$ & $\begin{array}{l}\text { After } \\
\text { Treatment } \\
\text { Mean } \pm \text { SD }\end{array}$ & $\begin{array}{l}\text { Change } \\
\text { Mean } \pm \text { SD }\end{array}$ & $\mathrm{t}$ & P - value \\
\hline $\begin{array}{l}\text { Angular } \\
\left({ }^{\circ}\right)\end{array}$ & $\begin{array}{l}\text { A Angle } \\
\text { H Angle }\end{array}$ & $\begin{array}{l}94.52 \pm 4.51 \\
8.69 \pm 3.67\end{array}$ & $\begin{array}{l}92.15 \pm 3.93 \\
12.77 \pm 3.38\end{array}$ & $\begin{array}{l}-2.36 \pm 2.77 \\
4.08 \pm 1.97\end{array}$ & $\begin{array}{l}-4.349 \\
10.562\end{array}$ & $\begin{array}{l}.000^{*} \\
.000^{*}\end{array}$ \\
\hline $\begin{array}{l}\text { Linear } \\
(\mathrm{mm})\end{array}$ & $\begin{array}{l}\text { UL-E } \\
\text { LL-E } \\
\mathrm{K}\end{array}$ & $\begin{array}{l}6.48 \pm 2.55 \\
-0.19 \pm 2.51 \\
11.88 \pm 2.30\end{array}$ & $\begin{array}{l}4.19 \pm 2.08 \\
0.63 \pm 1.74 \\
10.02 \pm 2.14\end{array}$ & $\begin{array}{l}-2.29 \pm 1.69 \\
0.83 \pm 2.02 \\
-1.86 \pm 0.62\end{array}$ & $\begin{array}{l}-6.896 \\
2.083 \\
-15.208\end{array}$ & $\begin{array}{l}.000^{*} \\
.048^{*} \\
.000^{*}\end{array}$ \\
\hline
\end{tabular}

${ }^{*} \mathrm{p}<.05$ statistically significant

Table 1 shows significant changes of all parameters. The $\mathrm{H}$ angle increased and soft tissue facial angle. A significant decreased in thickness was noted in soft tissue chin and the distance of upper lip to E-line while an increase was found in the distance lower lip to E-line. 
Table 2: Soft tissue changes after treatment with Class III activator compare with male and female and age group.

\begin{tabular}{|c|c|c|c|c|c|c|c|}
\hline \multirow[b]{2}{*}{ Variables } & \multirow[b]{2}{*}{ Sex } & \multicolumn{2}{|c|}{$\begin{array}{c}\text { 9-15 years } \\
\text { (Male-8 Female-11) }\end{array}$} & \multicolumn{2}{|c|}{$\begin{array}{c}\text { 16-22years } \\
\text { (Male-5 Female-2) }\end{array}$} & \multicolumn{2}{|c|}{$\begin{array}{c}\text { Total (9-22 years) } \\
\text { (Male-13 Female-13) }\end{array}$} \\
\hline & & $\begin{array}{c}\text { Mean } \\
\text { Change } \pm \text { SD }\end{array}$ & P-Value & $\begin{array}{c}\text { Mean } \\
\text { Change } \pm \text { SD }\end{array}$ & P-Value & $\begin{array}{c}\text { Mean } \\
\text { Change } \pm \text { SD }\end{array}$ & P-Value \\
\hline \multirow[t]{3}{*}{ A Angle $\left({ }^{\circ}\right)$} & Male & $-1.25 \pm 3.18$ & .304 & $-4.20 \pm 1.09$ & .001 & $-2.38 \pm 2.92$ & $.012 *$ \\
\hline & Female & $-2.09 \pm 2.74$ & .030 & $-3.75 \pm 3.18$ & .344 & $-2.35 \pm 2.73$ & $.009 *$ \\
\hline & Total & $-1.73 \pm 2.88$ & .017 & $-4.07 \pm 1.59$ & .001 & $-2.36 \pm 2.77$ & $.000 *$ \\
\hline \multirow[t]{3}{*}{ H Angle $\left({ }^{\circ}\right)$} & Male & $3.00 \pm 1.56$ & .001 & $3.80 \pm 2.49$ & .027 & $3.31 \pm 1.91$ & $.000 *$ \\
\hline & Female & $4.50 \pm 2.17$ & .000 & $3.25 \pm 1.77$ & .234 & $4.31 \pm 2.09$ & $.000^{*}$ \\
\hline & Total & $3.37 \pm 2.03$ & .000 & $3.63 \pm 2.17$ & .004 & $4.08 \pm 1.97$ & $.000 *$ \\
\hline \multirow{3}{*}{$\begin{array}{l}\text { UL-E line } \\
(\mathrm{mm})\end{array}$} & Male & $-1.00 \pm 0.89$ & .015 & $-3.70 \pm 1.92$ & .013 & $-2.04 \pm 1.89$ & $.002 *$ \\
\hline & Female & $-2.73 \pm 1.55$ & .000 & $-1.50 \pm 0.71$ & .205 & $-2.54 \pm 1.51$ & $.000^{*}$ \\
\hline & Total & $-2.00 \pm 1.55$ & .000 & $-3.07 \pm 1.92$ & .006 & $-2.29 \pm 1.69$ & $.000^{*}$ \\
\hline \multirow{3}{*}{$\begin{array}{l}\text { LL-E line } \\
(\mathrm{mm})\end{array}$} & Male & $2.31 \pm 2.02$ & .014 & $-0.70 \pm 1.92$ & .461 & $1.15 \pm 2.43$ & .113 \\
\hline & Female & $0.54 \pm 1.68$ & .307 & $0.25 \pm 0.35$ & .500 & $0.50 \pm 1.54$ & .265 \\
\hline & Total & $1.29 \pm 1.99$ & .011 & $-0.43 \pm 1.64$ & .516 & $0.83 \pm 2.02$ & $.048^{*}$ \\
\hline \multirow[t]{3}{*}{$\mathrm{K}(\mathrm{mm})$} & Male & $-1.75 \pm 0.75$ & .000 & $-2.40 \pm 0.74$ & .002 & $2.00 \pm 0.79$ & $.000^{*}$ \\
\hline & Female & $-1.72 \pm 0.41$ & .000 & $-1.75 \pm 0.35$ & .090 & $-1.73 \pm 0.39$ & $.000^{*}$ \\
\hline & Total & $-1.74 \pm 0.56$ & .000 & $-2.21 \pm 0.70$ & .000 & $-1.86 \pm 0.62$ & $.000^{*}$ \\
\hline
\end{tabular}

${ }^{*} \mathrm{p}<.05$ statistically significant

Table 2 Soft tissue facial angle decreased more in 16-22 years age group than 9-15 years age group in both male and female. H-line angle more increased in female specially 9-15 year's age group. Upper lip to E line distances decreased more in 16-22 years age group in male and 9-15 years group in female. Lower lip E line distances increased more in male than female specially 9-15 years age group. It is decreased in 16-22 years male age group and both age group in female but not significant. Soft tissue chin thickness more decreased in 16-22 years male age group.

Figure 6: Superimposition of cephalometric radiographs. (Soft tissue facial profile change)

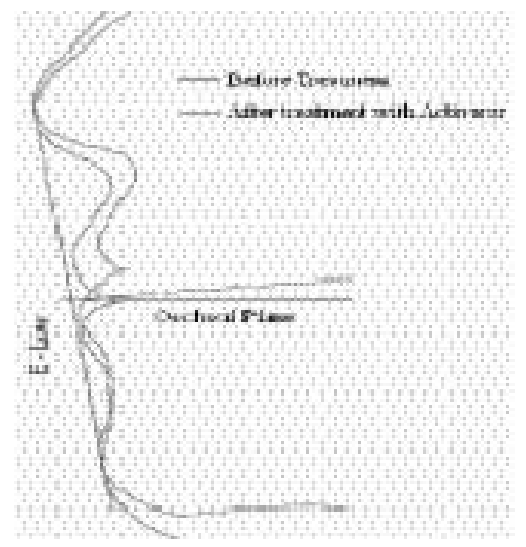

Assessing soft tissue facial profile change is to superimpose aesthetic line ( E-line) crossing at Occlusal plane of two serial cephalometric tracings. $($ Red line= before treatment; Blue line $=$ after treatment). Figure shows that after treatment the patients' soft tissue profile improved significantly compare with before treatment. 


\section{Case 1}

Before treatment

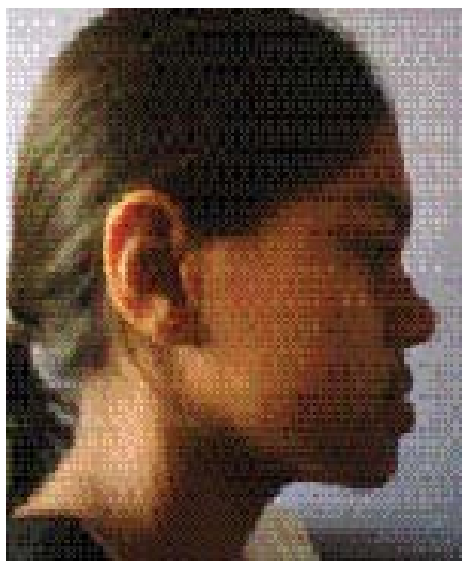

Activator in mouth

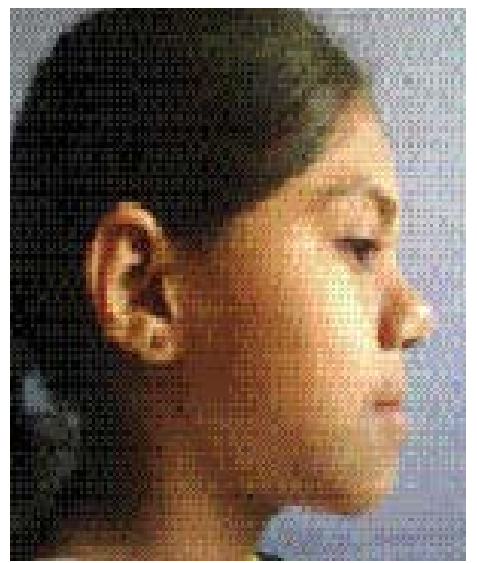

After treatment with Activator

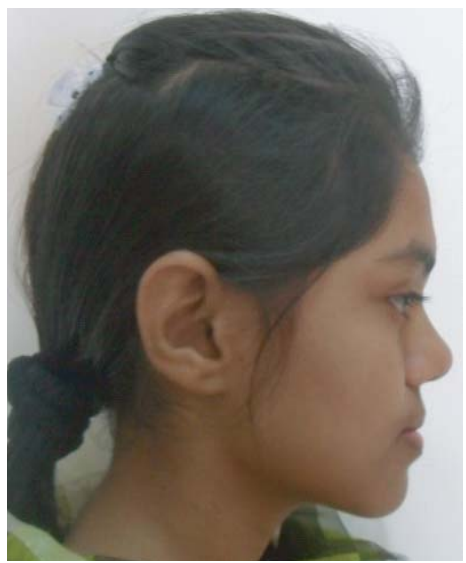

Soft tissue facial profile improved found in patients treated by Class III activator in skeletal Class III patients

\section{Case 2}

Before treatment

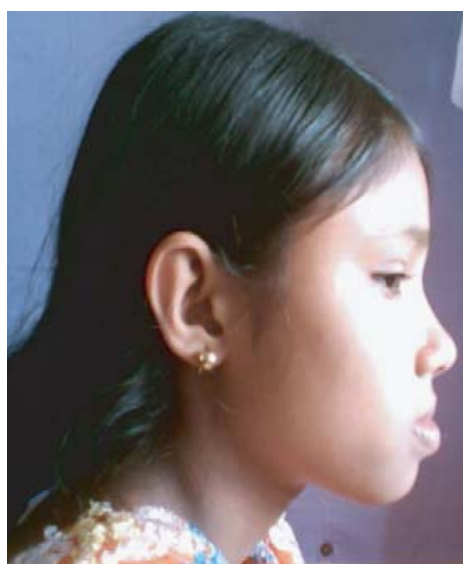

Activator in mouth

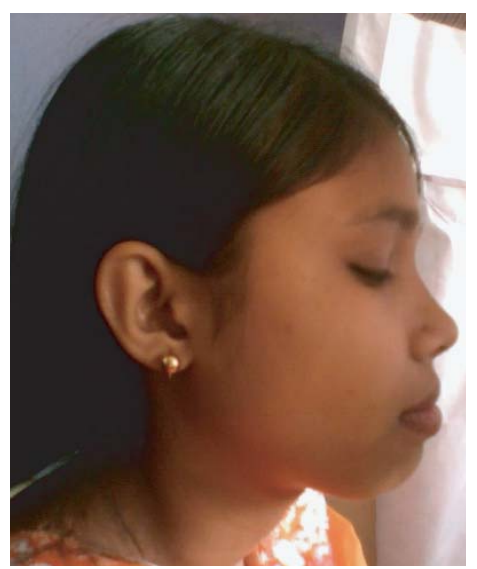

After treatment with Activator

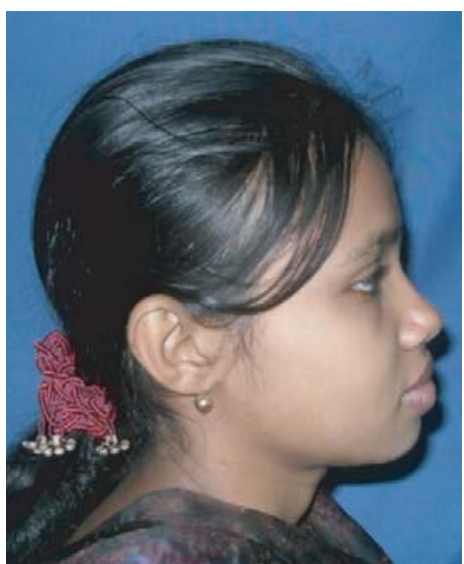

Soft tissue facial profile improved in patients treated by Class III activator in skeletal Class III patients

\section{DISCUSSION}

Clinically, patient with skeletal Class III malocclusion often present with a concave facial profile, a retrusive nasomaxillary area, and a prominent lower third of the face. The lower lip is often protruded to the upper lip. The results of the present study show that conventional Class III activator (Andresen appliance), in the treatment of skeletal Class III malocclusion can result in beneficial effects on the maxillofacial complex and skeletal and facial soft tissues.

Various soft tissue changes combined to improve the Class III profile a forward movement of upper lip, backward movement of lower lip and decrease in soft tissue chin thickness, contributed to the profile more convex related to Class III concave profile. This results correlate with those of Ngan -1998 and Kilicoglu and kirlic-1998.2,23 A significant decreased in thickness was noted in soft tissue chin $\left(-1.86 \pm 0.62^{\circ}, \mathrm{p}<.000\right)$ and the distance of upper lip to E-line $\left(-2.29 \pm 1.69^{\circ}, \mathrm{p}<.000\right)$ while an increase was found in the distance lower lip to $\mathrm{E}-$-line $\left(0.83 \pm 2.02^{\circ}, \mathrm{p}<.048\right)$ giving a $\mathrm{H}$ angle difference $4.08 \pm 1.97, \mathrm{p}<.000$. Soft tissue facial angle decreased $(-2.36 \pm 2.77, \mathrm{p}<.000)$ and more in $16-22$ years age group than 9-15 years age group in both male and female. Upper lip to $\mathrm{E}$ line distances decreased more in 16-22 years age 
group in male and 9-15 years group in female. Lower lip E line distances increased more in male than female specially 9-15 years age group. It is decreased in 16-22 years male age group and both age group in female but not significant. Soft tissue chin thickness more decreased in 16-22 years male age group. The most of the variable changes more in Bangladeshi population, which observed in present study probably due to structural difference of individuals, or co operation of the patients.

\section{CONCLUSION}

Based on the cephalometic alteration observed after treatment with Class III activator, in conclusion followings are suggested: No statistically significant changes were observed in mandible but restriction of forward movement of mandible was beneficial. The Class III concave profile became more balanced with an improvement of soft tissue and underlining skeleton.

\section{REFERENCES}

1. Arman A, Toygar TU, Abuhijleh E. Profile changes associated with different orthopedic treatment approaches in Class III malocclusions. Angle Orthod. 2004 Dec;74(6):733-40.

2. Ngan P, Wei S H Y. Early treatment of Class III patient to improve facial aesthetics and predict future growth. Hong Kong Dental Journal. 2004; 1: 24-30

3. Kharbanda Om P. Class III malocclusion in growing patients. In: Orthodontics Diagnosis and management of Malocclusion and Dentofacial deformities. First ed. Elsevier 2009. 403-414.

4. McNamara Jr, J. A. and W. L. Brudon . Orthodontic and Orthopedic Treatment in the Mixed Dentition. Ann Arbor, Mich: Needham Press Inc; 1993:117-118.

5. Kerr, W. J. S. and T. R. Ten Have . Changes in soft tissue profile during the treatment of Class III malocclusion. Br J Orthod 1987. 14:243-249.

6. Kerr, W. J. S. and T. R. Ten Have . A comparison of three appliance systems in the treatment of Class III malocclusion. Eur J Orthod 1988. 10:203-214.

7. Fränkel, R. and C. Fränkel . Orofacial Orthopedics with the Function Regulator. Munich, Germany: S Karger; 1989:12-40.

8. Mulatta after application of a continuous-acting retraction force on the mandible. Am J Orthod 1965. 51:823-855.

9. Joho, J. P. The effects of extraoral low pull traction to the mandibular dentition of Macaca Mulatta. Am J Orthod 1973. 64:555-577.

10. Petrovic, A. G. , J. J. Stutzmann , and J. L. Oudet . Control processes in the postnatal growth of the condylar cartilage of the mandibleEffect of orthopedic therapy on condylar growth. In: McNamara JA Jr, ed. Determinants of Mandibular Form and Growth. Ann Arbor,
Mich: University of Michigan; 1975:101-153.

11. Graber, L.W. Chincup therapy for mandibular prognathism. Am J Orthod 1977. 72:23-41

12. Mitani, H. and H. Fukazawa . Effects of chincup force on the timing and amount of mandibular growth associated with anterior reversed occlusion (Class III malocclusion) during puberty. Am J Orthod Dentofacial Orthop 1986. 90:454-463.

13. Cozzani, G. Extraoral traction and Class III treatment. Am J Orthod 1981. 80:638-650

14. Battagel, J. M. and H. S. Orton. Class III malocclusion: the postretention findings following a non-extraction treatment approach. Eur J Orthod 1993. 15:45-55.

15. Battagel, J. M. and H. S. Orton . A comparative study of the effects of customized facemask therapy or headgear to the lower arch on the developing Class III face. Eur J Orthod 1995. 17:467-482.

16. Tanne, B. K. and M. Sakuda . Biomechanical and clinical changes of the craniofacial complex from orthopedic maxillary protraction. Angle Orthod 1991. 61:145-151.

17. Takada, K. , S. Petdachai , and M. Sakuda . Changes in dentofacial morphology in skeletal Class III children treated by a modified maxillary protraction headgear and a chincup: a longitudinal cephalometric appraisal. Eur J Orthod 1993. 15:211-221

18. Westwood, P. V. , J. A. McNamara Jr, T. Bacetti , L. Franchi, and D. M. Sarver . Long-term effects of Class III treatment with rapid maxillary expansion and facemask therapy followed by fixed appliances. Am J Orthod Dentofacial Orthop 2003. 123:306-320.

19. Hossain MZ et al. A case report of successful orthopedic \& orthodontic correction of Class II malocclusion using myofunctional appliance. J of Oral Health 1991-2; 8: 36-40

20. Hossain MZ, Tarique A A M, Haque S, Khaleque KA. Two stage treatment of a pseudoskeletal Class III. J of Oral Health Oct' 2003;5(2), 24-27

21. Donald G woodside. The Harvold- Woodside activator In: Graber TM, Neumann Bedrich. Removable Orthodontic Appliance 2nd ed. 1984; 244-309

22. Kiliçoglu, H. and Y. Kirliç . Profile changes in patients with Class III malocclusions after Delaire mask therapy. Am J Orthod Dentofacial Orthop 1998. 113:453-462.

23. Cobo, J., J. Baladron, M. Vijande, J. L. Arranz, and J. Casteigt . Densitometric evaluation of changes in the soft tissue of the chin and the lower lip during the treatment of Class III malocclusion. Int J Adult Orthod Orthognath Surg 1992. 7:89-95

24. Ngan P, Hagg U, Yiu C, Merwin D, Wei S H Y, Gunel E. Cephalometric and occlusal changes following maxillary expansion and protraction headgear treatment. American Journal of Orthodontics and Dentofacial Orthopedics. 1998: 20: 237-254

25. Üçüncü, N., T. Tortop Üçem, and S. Yüksel . A comparison of chincup and maxillary protraction appliances in the treatment of skeletal Class III malocclusions. Eur J Orthod 2000. 22:43-51

\section{Correspondence}

Dr. Mohammad Shamim Al Mamun

BDS, FCPS (Ortho)

Asst Prof. and Head,Dept of Orthodontics

University Dental College and Hospital

Cell: +88-01712718527 E-mail: mamun_d36@yahoo.com 